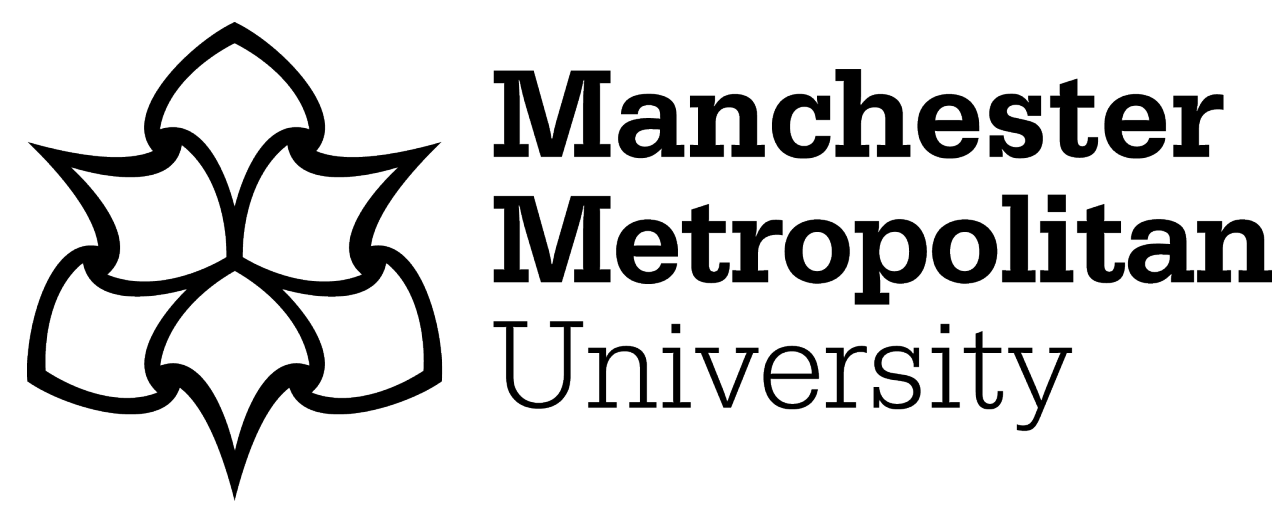

Vanderschelden, Isabelle ORCID logoORCID: https://orcid.org/0000-00021566-5246 (2017) Book Review: The films of Eric Rohmer French new wave to old master. Modern \& Contemporary France, 25 (2). pp. 225-226. ISSN 0963-9489

Downloaded from: https://e-space.mmu.ac.uk/627162/

Version: Accepted Version

Publisher: Informa UK Limited

DOI: https://doi.org/10.1080/09639489.2017.1308328

Please cite the published version 


\section{The films of Eric Rohmer French new wave to old master}

\section{Isabelle Vanderschelden}

To cite this article: Isabelle Vanderschelden (2017) The films of Eric Rohmer French new wave to old master, Modern \& Contemporary France, 25:2, 225-226, DOI: 10.1080/09639489.2017.1308328

To link to this article: https://doi.org/10.1080/09639489.2017.1308328

\section{Published online: 02 May 2017.}

Submit your article to this journal $₫$

山ll Article views: 26

Q View related articles $\longleftarrow$

View Crossmark data \lceil 
The films of Eric Rohmer. French new wave to old master, edited by Leah Anderst, Basingstoke, Palgrave Macmillan, 2014, 268 pp., £60.00 (hardback), ISBN: 978-1-13701099-5

Eric Rohmer may not have reached the levels of popularity of his New Wave friends Godard or Truffaut, but his films are art-house classics widely available in the anglophone world. Some classic films such as the series known as the 'Contes moraux', the 'Comédies et proverbes' and the 'Contes des quatre saisons' figure in many university courses. His work has attracted sustained attention with several recent monographs published in English since he died in 2010 and a thick biography by the French critics and film historians Antoine de Baecque and Noël Herpe also appeared in 2016 in translation.

This international collection of essays edited by Leah Anderst addresses the legacy of the artist from a range of critical perspectives, and includes contributions from established American scholars of French cinema such as Dudley Andrew, Tom Gunning, Jefferson Kline and Derek Schilling, in addition to translated essays from the already mentioned experts Herpe and de Baecque. It also brings in authors from other disciplines, offering new insights into Rohmer's rich filmography and his legacy to philosophy, auteur theory, narratology and other artistic strands.

The essays are grouped into broad thematic sections, including criticism, narration, gender politics and literary adaptation. They highlight important facets of the auteur's identity as a film critic who was influenced by his mentor, André Bazin, before becoming the New Wave director who has transformed our perception of cinematic narrative, genre, ethics, language and form.

The collection of essays also constantly reminds us of the extent to which Rohmer's world was infused by French cultural tradition—cinephilia, but also philosophy, key historical moments and particularly French literature (La Bruyère). They address more specifically the original ways in which he explored language in his films, reassessing its ontology and revisiting questions of realism.

Some of the contributions focus on Rohmer's classics from the 1960s, such as Matthew Thorpe's and André Aciman's reflections on Ma nuit chez Maud (1969), a film that remains a favourite landmark in Rohmer's filmography. Other essays revisit familiar motifs such as the moral dimension at the centre of Rohmer's auteurist project, the distinctive use of language that characterises many Rohmerian protagonists and his slow-paced narratives. Keith Tester, for example, develops the notion of 'fissure' to analyse the 'Contes des quatre saisons'. Some of the contributions, such as de Baecque's and Gunning's, approach Rohmer's work from lesser studied political angles. Aimée Israel-Pelletier's analysis of gender politics complements Mary Harrod's association of Rohmer's cinema with the American genre of melodrama. Rohmer's films are often geographically explicit with identified locations, and it is no surprise that a section should be devoted to place and space. Anderst's contribution discusses the use of 'place (lessness)' and space in the films, while Fiona Handyside focuses on flânerie and Rohmer's use of Parisian spaces.

This collection of essays is not intended as an introduction to Rohmer's cinema and assumes familiarity with his filmography, including some lesser-known films such as L'Arbre, le maire et la médiathèque (1993). The contextual information is limited to what is directly relevant to the argument, even if the general introduction provides valuable guidance on how to approach Rohmer's art. The critical conceptual frameworks used by the different contributors also require some previous knowledge and understanding of film and cultural studies, narrative theory and philosophy. The individual analyses are focused and precise, but directed primarily at academic audiences. What this collection clearly shows, however, is that the universal dimension of Rohmer's 
motifs calls for endless reinterpretation. The authors show, in their own way, that, far from having turned into an 'old master' as suggested in the (sub)title, Rohmer has throughout his career reinvented the creative potential of cinema, and become a major figure of world art cinema. The emphasis that this volume places on the different ways to approach his cerebral tales, their spaces, themes and characters clearly indicates how elusive Rohmer's art can appear on the surface, but also proves that the films remain relevant today and are still open to multiple readings.

\section{Isabelle Vanderschelden \\ Manchester Metropolitan University \\ Qi.vanderschelden@mmu.ac.uk}

(C) 2017 Isabelle Vanderschelden

http://dx.doi.org/10.1080/09639489.2017.1308328

Check for updates

The last Communard. The story of an unexpected hero, by Gavin Bowd, London, Verso, 2016, 192 pp., £14.99, hbk, ISBN: 978-1-78-478285-6

The onomastic irony of Lejeune's story is that it is ultimately a sad tale of simple senescence: he long outlived his comrades, becoming 'a "relic" of a cause' (168). A geriatrician's office now adorns the street bearing his name in Bagnolet. Even his grateful Soviet benefactors recognised that the combination of his longevity with their own limited resources had contrived to produce an 'eternal Lejeune problem' (82). In researching his meticulously careful study of this long life, Gavin Bowd has scoured police, national and press archives in France and Russia in search of the truth about a secular saint. He tries to see past Lejeune's own manoeuvring to avoid the firing squad and through layer upon misleading layer of subsequent commentary, memorialisation and propagandistic instrumentalisation of this survivor and the uprising in which he participated. The final verdict, that Lejeune was 'not the heroic Communard of Communist hagiography' (165), is perhaps unsurprising but there are some significant discoveries of fact along the way, in particular that Lejeune was not deported to New Caledonia, unlike many of the other Communards who survived 'la Semaine sanglante', and that he must have left Paris for Moscow not on one of the several dates in the 1920s given in rival existing accounts, but in 1930. Once in the Soviet Union, although Lejeune was idolised and even assigned a state carer and companion by the NKVD in the form of the devoted Adela Nikolova, whose reports and letters offer the most touching testimony in this book, he was anything but docile. Bowd's account of his cantankerous missives home to request wine, chocolate and other luxuries-as well as of his correspondents' attempts to placate him - provide personal and material density to this thorough investigation of Lejeune's story. Some readers may think that the direct quotations from press and archival sources are too extensive and too numerous. I felt there was a somewhat disconcerting tendency to treat police archives, whether those of the Versaillais repression or those of the NKVD, as inherently more authoritative and reliable than other sources, and at times the book gets caught up in the drama of its own sleuthing for a 'darker reality' (72) behind Lejeune's public image. And I would have liked to know a little more than is revealed in the scene-setting introductory chapter about Bowd's own particular interest in Lejeune and his legend.

Oliver Davis

University of Warwick

@O.Davis@warwick.ac.uk 